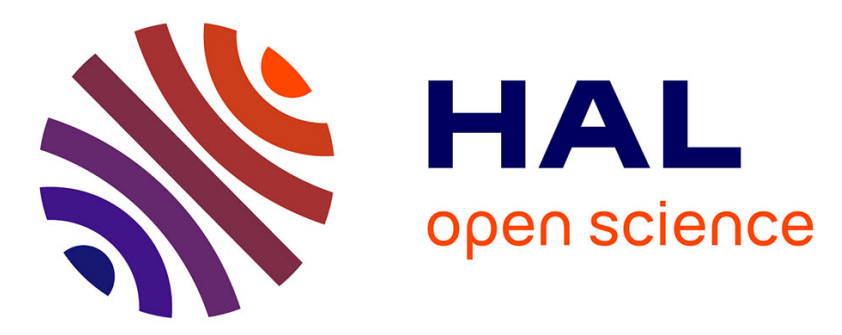

\title{
Determination of the Noise Floor of the WHISPER instrument on Cluster
}

Helen Middleton, Harri Laakso, Arnaud Masson, Xavier Vallières

\section{To cite this version:}

Helen Middleton, Harri Laakso, Arnaud Masson, Xavier Vallières. Determination of the Noise Floor of the WHISPER instrument on Cluster. 14th Europlanet Science Congress 2020, 2020, Online, France. 10.5194/epsc2020-627 . insu-03560702

\section{HAL Id: insu-03560702 \\ https://hal-insu.archives-ouvertes.fr/insu-03560702}

Submitted on 8 Feb 2022

HAL is a multi-disciplinary open access archive for the deposit and dissemination of scientific research documents, whether they are published or not. The documents may come from teaching and research institutions in France or abroad, or from public or private research centers.
L'archive ouverte pluridisciplinaire HAL, est destinée au dépôt et à la diffusion de documents scientifiques de niveau recherche, publiés ou non, émanant des établissements d'enseignement et de recherche français ou étrangers, des laboratoires publics ou privés.

\section{(c)(1)}

Distributed under a Creative Commons Attribution| 4.0 International License 
EPSC Abstracts

\title{
Determination of the Noise Floor of the WHISPER instrument on Cluster
}

\author{
Helen Middleton ${ }^{1}$, Harri Laakso ${ }^{1}$, Arnaud Masson ${ }^{1}$, and Xavier Vallières ${ }^{2}$ \\ ${ }^{1}$ ESA/ESAC, Madrid, Spain (helen.middleton@esa.int) \\ ${ }^{2} \mathrm{LPC} 2 \mathrm{E} / \mathrm{CNRS}$, Orleans, France
}

The WHISPER (Waves of HIgh frequency and Sounder for Probing of Electron density by Relaxation) instrument is part of the WEC (Wave Experiment Consortium) of the ongoing Cluster mission, launched almost 20 years ago in 2000. It uses the long double sphere electric dipole antennas of the EFW (Electric Field and Wave) instrument to measure the electric field spectra in the frequency range $2-80 \mathrm{kHz}$.

The characteristic signatures of natural or actively triggered waves indicate the nature of the ambient plasma regime and, combined with the spacecraft position, reveals the position of key magnetospheric boundaries encountered during a specific time interval.

Most of the time, WHISPER observes natural waves in the 2-80 kHz band, using one of the two EFW antennae pairs: Ey or Ez, which can have different characteristics. After successive technical problems with the EFW sensors, the receiving antenna had to be changed on 3 of the 4 spacecraft over the years, and Cluster 1 (C1) WHISPER measurements are currently being made with only one probe (the spacecraft acts as the second probe).

In order to understand the signals observed by the WHISPER experiment, one needs to know the instrumental noise floor, around which the measurements are meaningless. It is a frequent feature of wave detectors that this noise floor is temporally static - it does not degrade with time. However, what this noise floor actually is, and how its behaviour changes around the failure of probes and switching to other probes is the purpose of this study.

The NATURAL spectra were processed orbit by orbit, in order to avoid strong emissions from any one region, then the minimum value for the low-energy spectra was picked out for each frequency. Individually, these show a large amount of variation, but the median of 20 orbits gives a very reproducible curve showing how the noise floor varies with frequency. The periods before, during and after probe failures and configuration changes were investigated and show the limited changes to the curves and strength of interference lines. 